\title{
Establishment and Evaluation of Polymerase Chain Reaction for Detection of Y-Chromosome-Specific Fetal DNA in Maternal Blood Circulation during Pregnancy and after Delivery
}

\author{
M.K. Al-Yatama ${ }^{a, c}$ A.S. Mustafab ${ }^{b}$ A.E. Omu ${ }^{a, c}$ S. Alia ${ }^{a}$ S. Abraham ${ }^{a}$ \\ K. Zohra ${ }^{a}$ Nawal Khaja $^{c}$ \\ Departments of a Obstetrics and Gynaecology and ${ }^{b}$ Microbiology, Faculty of Medicine, Kuwait University, and \\ 'Maternity Hospital, Kuwait
}

\section{Key Words}

Fetal DNA $\cdot$ Y chromosome $\cdot$ Maternal blood $\cdot$ Nested polymerase chain reaction

\begin{abstract}
Objective: To establish and evaluate nested polymerase chain reaction (PCR) for detection of Y-chromosome-specific fetal DNA in maternal blood circulation during pregnancy and its clearance several days after delivery. Materials and Methods: Genomic DNA was isolated from a male donor to amplify $Y$-chromosome-specific DNA sequences by using four pairs of oligonucleotide primers targeting single or multiple copy genes in standard and nested PCR. The nested PCR was evaluated for detection of Y-chromosome-specific sequences in the maternal blood circulation of pregnant women bearing a male fetus during pregnancy and at 2 and $24 \mathrm{~h}$ and 7 days after delivery. Results: Although both standard and nested PCR assays were established by using genomic DNA from a male donor to detect $Y$-chromosome-specific DNA sequences, the nested PCR was 10 times more sensitive than standard PCR. Further experiments showed that nested PCR was able to detect Y-chromosome-spe-
\end{abstract}

cific DNA in the peripheral blood cells as well as in the plasma and serum of pregnant women carrying a male fetus. When tested with plasma samples from women carrying male fetuses during pregnancy, nested PCR was positive with 53/55 (96\%), 22/22 (100\%), 16/22 (73\%) and $0 / 30(0 \%)$ specimens obtained before and at 2 and $24 \mathrm{~h}$ and 7 days after delivery, respectively. These results showed that fetus-specific Y-chromosome DNA was cleared from maternal circulation within 7 days of delivery. Conclusion: Our results suggest that nested PCR is useful in fetal sex determination and that prenatal diagnosis can be done without interference from previous pregnancy.

Copyright $(2001$ S. Karger AG, Basel

\section{Introduction}

The noninvasive recovery of fetal cells from maternal blood coupled with chromosomal and genetic diagnostic techniques can potentially revolutionize prenatal diagnosis. Fetal cells such as trophoblasts, lymphocytes and nucleated red cells (erythroblasts) have been shown to exist in maternal blood during pregnancy [1-5]. However,

\begin{tabular}{ll}
\hline KARGER & ( 2001 S. Karger AG, Basel \\
$1011-7571 / 01 / 0104-0171 \$ 17.50 / 0$ \\
$\begin{array}{l}\text { Fax +41613061234 } \\
\begin{array}{l}\text { E-Mail karger@karger.ch } \\
\text { www.karger.com }\end{array}\end{array}$ & $\begin{array}{l}\text { Accessible online at: } \\
\text { www.karger.com/journals/mpp }\end{array}$
\end{tabular}

Dr. Majda K. Al-Yatama
Department of Obstetrics and Gynaecology
Faculty of Medicine, Kuwait University
PO Box 24923, 13110 Safat (Kuwait)
Tel. +965 531 9601, Fax +965 533 8906, E-Mail sobha@hsc.kuniv.edu.kw 
syncytiotrophoblast cells, not expressing HLA class I and II antigens, do not induce a maternal immunological response. Having originated from previous pregnancies, these cells may survive in maternal blood and therefore are not applicable in prenatal diagnosis [6]. Recent studies suggest that fetal lymphocytes do not as readily cross the placenta as originally believed [7]. Nucleated red blood cells seem to be the promising cell type for prenatal diagnosis because they are relatively short-lived, and therefore the likelihood that these cells originated in prior pregnancies is reduced $[2,5]$. It has previously been shown that fetal-nucleated red blood cells may be present in the maternal blood as early as 8 weeks of gestation, thus permitting first trimester diagnosis of fetal aneuploidy [4]. However, the relative paucity of fetal erythroblasts in maternal blood cells (estimated ratio of $1: 1 \times 10^{7}$ to $1: 1$ $\times 10^{8}$ cells), and therefore in each collected sample, complicates their potential in prenatal diagnosis [7]. Retrieval of fetal cells from maternal blood can be enhanced by enrichment techniques involving fluorescence-activated cell sorting and magnetic-activated cell sorting [8, 9]. However, most enrichment and purification techniques are time-consuming and require expensive equipment.

Recently, there has been much interest in the use of DNA derived from plasma and serum for the molecular diagnosis of genetic abnormalities and tumors [10-12]. Furthermore, it has been shown that fetus-specific DNA exists in maternal circulation $[12,13]$ and can be detected as early as 7 weeks of gestation $[14,15]$. These studies demonstrate that DNA from cells dying in the developing embryo passes through both placental and kidney barriers to appear in the maternal circulation; the size of DNA fragments in serum and plasma is sufficient to provide polymerase chain reaction (PCR) analysis, and the amount of fetal DNA in the mother's plasma is high enough to serve as a target for the detection of multiple as well as single copy genes. However, to be of value in prenatal diagnosis, the fetus-specific DNA should be cleared from the maternal circulation within a reasonable time period after delivery, so that previous pregnancies do not have any effect on the results of prenatal diagnosis. However, there is only one reported study [16] using quantitative PCR to investigate the clearance of male-specific fetal DNA from maternal plasma within $24 \mathrm{~h}$ after delivery [16].

Therefore in the present study, we have established and evaluated the use of highly sensitive nested PCR for the detection of the presence of Y-chromosome-specific DNA in the maternal circulation during pregnancy and its clearance several days after delivery.

\section{Materials and Methods}

\section{Donor Groups and Specimens}

Peripheral blood cells form male donors were used for standardization experiments. The experimental group consisted of pregnant women attending the outpatient clinic at the Maternity Hospital, Kuwait. All the donors consented to participate in the study. The study procedure was approved by the Ethical Committee, Faculty of Medicine, Kuwait University, Kuwait. To obtain whole blood, plas$\mathrm{ma}$ and serum samples, peripheral blood $(5-10 \mathrm{ml})$ was collected from donors carrying male fetuses during pregnancy $(\mathrm{n}=55)$ and $2 \mathrm{~h}$ $(\mathrm{n}=22), 24 \mathrm{~h}(\mathrm{n}=22)$ and 7 days $(\mathrm{n}=30)$ after delivery. To avoid false positivity, separate facilities were used for sample preparation, amplification and analysis of the amplified products. In addition, specimens from 40 positive and 25 negative controls were included in all the experiments using clinical specimens. Each positive control contained $10 \mathrm{pg}$ of male genomic DNA extracted from the whole blood. Negative controls were extraction and reagent controls as described by Mustafa et al. [17].

\section{Isolation of DNA from Whole Blood}

DNA from whole blood was isolated using standard procedures described previously [18]. In brief, $500 \mu 1$ of whole blood was treated with red cell lysis buffer and centrifuged. The pellet was resuspended in $16 \mu$ l of $\times 5$ proteinase-K buffer, $4 \mu$ l proteinase-K enzyme $(10$ $\mathrm{mg} / \mathrm{ml}), 4 \mu \mathrm{l} 20 \%$ sodium dodecyl sulfate and $30 \mu \mathrm{l}$ distilled water. The tube was incubated with slow rotation at $55^{\circ} \mathrm{C}$ for $2-4 \mathrm{~h}$. The DNA was then precipitated with $70 \%$ ethanol, the pellet air-dried, dissolved in $50 \mu \mathrm{l} \mathrm{TE}$ buffer and $10 \mu \mathrm{l}$ used for PCR.

\section{Isolation of DNA from Plasma and Serum}

Plasma and serum samples were processed by a modified method described by Lo et al. [12]. In brief, $200 \mu \mathrm{l}$ of each plasma or serum sample was heated at $99^{\circ} \mathrm{C}$ for $5 \mathrm{~min}$. The sample was centrifuged, supernatant collected and $10 \mu \mathrm{l}$ was used for PCR.

\section{Primers for the Detection of Y-Chromosome}

To amplify Y-chromosome-specific DNA sequences, four primer pairs were used. Following are the designation and the nucleotide sequence of the primers and the size of target DNA to be amplified:

$\begin{array}{lll}\text { Y1.1 } & \text { 5'-TCCACTTTATTCCAGGCCTGTCC-3' } & \\ \text { Y1.2 } & \text { 5'-TTGAATGGAATGGGAACGAATGG-3' }^{\prime} 154 \mathrm{bp} \\ \text { Y1.3 } & \text { 5'-CCATTCCTTTGCTTCCGTTTCC-3' } & \\ \text { Y1.4 } & \text { 5'-ATCGACTGGCAGGGAACCAAAAG-3' } & 95 \mathrm{bp} \\ \text { Y1.5 } & \text { 5'-CTAGACCGCAGAGGCGCCAT-3' } & \\ \text { Y1.6 } & \text { 5'-TAGTACCCACGCCTGCTCCGG-3' } & 243 \mathrm{bp} \\ \text { Y1.7 } & \text { 5'-CATCCAGAGCGTCCCTGGCTT-3' } & \\ \text { Y1.8 } & \text { 5'-CTTTCCACAGCCACATTTGTC-3' } & 198 \mathrm{bp}\end{array}$

The 95- and 198-bp DNA fragments are internal to the 154- and 243-bp sequences, respectively. The DNA targets for Y1.1/Y1.2 and $\mathrm{Y}$.1.3/Y1.4 are present in 2-5 copies whereas the targets for $\mathrm{Y} 1.5 /$ $\mathrm{Y} 1.6$ and $\mathrm{Y} 1.7 / \mathrm{Y} 1.8$ are present in a single copy in the $\mathrm{Y}$ chromosome $[19,20]$.

\section{PCR and Detection of Amplified DNA}

By using the oligonucleotide primers described above, Y-chromosome-specific DNA fragments were amplified according to the standard procedures described previously [17]. In brief, each reaction 
mixture $(100 \mu \mathrm{l})$ contained $200 \mathrm{n} M$ of each relevant primer and 2.5 U of AmpliTaq DNA polymerase, PCR buffer, dNTPS and target DNA. Amplification was carried out in a thermal cycler (Perkin Elmer System 2400). The standard PCR was performed for 45 cycles. For a nested PCR, $10 \mu \mathrm{l}$ of reaction mixture, after completion of standard PCR with primer pairs $\mathrm{Y} 1.1 / \mathrm{Y} 1.2$ and $\mathrm{Y} 1.5 / \mathrm{Y} 1.6$, was reamplified for 20 cycles in a second step with the primer pairs $Y 1.3 /$ $\mathrm{Y} 1.4$ and $\mathrm{Y} 1.7 / \mathrm{Y} 1.8$, respectively. Each cycle in standard as well as nested PCR consisted of denaturation at $95^{\circ} \mathrm{C}$ for $15 \mathrm{~s}$, annealing at $60^{\circ} \mathrm{C}$ for $30 \mathrm{~s}$, and extension at $72^{\circ} \mathrm{C}$ for $45 \mathrm{~s}$. The amplified DNA was analyzed by agarose gel electrophoresis according to standard procedures [17]. The bands for specific DNA were observed under UV light and photographed.

\section{Results}

To establish PCR assays for detection of Y-chromosome-specific DNA sequences, genomic DNA was isolated from peripheral blood of a male donor and used with all the four primer pairs (Y1.1/Y1.2, Y1.3/Y1.4, Y1.5/ $\mathrm{Y} 1.6$ and $\mathrm{Y} 1.7 / \mathrm{Y} 1.8)$. Each primer pair was added to reaction mixtures in separate reaction tubes and the amplification was done for 45 cycles. The results showed that DNA fragments of expected size were amplified with all the four primer pairs in standard PCR (fig. 1). Moreover, all the primer pairs had the same sensitivity of target detection, i.e. the detection limit in each case was $125 \mathrm{pg}$ genomic DNA equivalent to 38 cells (table 1). Thus the sensitivity of detection with multiple copy targets (2-5 copies) of primer pairs $\mathrm{Y} 1.1 / \mathrm{Y} 1.2$ and $\mathrm{Y} 1.3 / \mathrm{Y} 1.4$ was the same as that of single copy targets amplified by the primer pairs $\mathrm{Y} 1.5 / \mathrm{Y} 1.6$ and $\mathrm{Y} 1.7 / \mathrm{Y} 1.8$.

To improve the sensitivity of detection of Y-chromosome-specific DNA fragments, nested PCRs were developed first by using outer primers $\mathrm{Y} 1.1 / \mathrm{Y} 1.2$ and $\mathrm{Y} 1.5 /$ Y1.6 in the standard PCR, followed by reamplification with the internal primers $\mathrm{Y} 1.3 / \mathrm{Y} 1.4$ and $\mathrm{Y} 1.7 / \mathrm{Y} 1.8$, respectively. The results showed that the nested PCR improved the sensitivity of detection by $\times 10$ (data not shown). This improved sensitivity of the nested PCR was further confirmed by testing blood specimens from a pregnant woman bearing a male fetus. The specimens did not show the presence of Y-chromosome-specific DNA in standard PCR by using primers Y1.1/Y1.2 (fig. 2, lanes 2 and 4). However, the same specimens in the nested PCR showed the presence of Y-chromosome-specific 95-bp DNA in blood (fig. 2, lanes 5 and 7). The negative control specimen remained negative with standard PCR (fig. 2, lane 3) as well as with nested PCR (fig. 2, lane 6). Further-

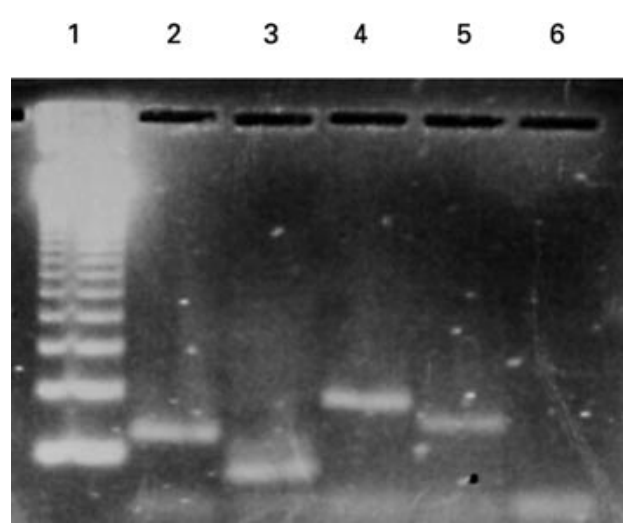

Fig. 1. Amplification of Y-chromosome-specific DNA sequences in standard PCR using genomic DNA from a male donor. Genomic DNA isolated from peripheral blood of a male donor was used to amplify Y-chromosome-specific DNA by using Y-chromosome-specific primers in standard PCR as described in 'Materials and Methods'. Negative controls lacked the genomic DNA. The PCR products were analyzed by gel electrophoresis as described in the 'Materials and Methods' section. Lane 1 = Molecular weight marker (123-bp DNA ladder), lane $2=154 \mathrm{bp}$ DNA amplified with primers $\mathrm{Y} 1.1$ and Y1.2; lane $3=95$ bp DNA amplified with primers Y1.3 and Y1.4; lane $4=243$ bp DNA amplified with primers $Y 1.5$ and $Y 1.6$; lane $5=$ 198 bp DNA amplified with primers Y1.7 and Y1.8; lane $6=$ negative control with primers Y1.1 and Y1.2. Similar negative results were obtained with other primers.
Table 1. Sensitivity of detection of Y-chromosome-specific DNA with standard PCR by using Y-chromosomespecific primers and genomic DNA isolated from peripheral blood cells of a male donor

\begin{tabular}{|c|c|c|c|c|c|c|}
\hline \multirow[t]{2}{*}{ Primers } & \multirow{2}{*}{$\begin{array}{l}\text { Size of } \\
\text { target DNA } \\
\text { bp }\end{array}$} & \multicolumn{5}{|c|}{ PCR results with different quantities of genomic DNA } \\
\hline & & $1,250 \mathrm{pg}$ & $125 \mathrm{pg}$ & $12.5 \mathrm{pg}$ & $1.25 \mathrm{pg}$ & $0.0 \mathrm{pg}$ \\
\hline $\mathrm{Y} 1.1 / \mathrm{Y} 1.2$ & 154 & + & + & - & - & - \\
\hline Y1.3/Y1.4 & 95 & + & + & - & - & - \\
\hline Y1.5/Y1.6 & 243 & + & + & - & - & - \\
\hline $\mathrm{Y} 1.7 / \mathrm{Y} 1.8$ & 198 & + & + & - & - & - \\
\hline
\end{tabular}

PCR for Detection of

Y-Chromosome-Specific DNA
Med Principles Pract 2001;10:171-176 


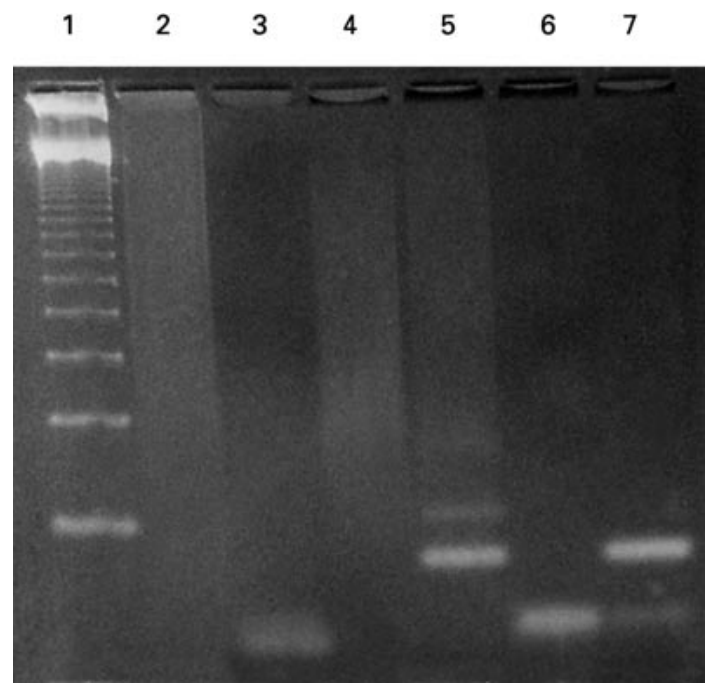

Fig. 2. Standard and nested PCR using DNA isolated from peripheral blood of a pregnant woman bearing a male fetus. Genomic DNA isolated from peripheral blood of a pregnant woman carrying a male fetus was subjected to standard PCR by using primers Y1.1 and Y1.2. The nested PCR was performed by reamplification of $10 \mu \mathrm{l}$ product from standard PCR with primers Y1.3 and Y1.4. Negative control lacked the genomic DNA. The products were analyzed by gel electrophoresis as described in the 'Materials and Methods' section. Lane 1 = Molecular weight marker (123-bp DNA ladder); lanes 2 and 4 = standard PCR with genomic DNA from peripheral blood and primers $\mathrm{Y} 1.1$ and $\mathrm{Y} 1.2$; lane $3=$ standard $\mathrm{PCR}$ with negative control and primers $\mathrm{Y} 1.1$ and $\mathrm{Y} 1.2$; lane $5=$ nested PCR with $10 \mu 1$ standard PCR product from the reaction loaded in lane 2 and primers $\mathrm{Y} 1.3$ and Y1.4; lane $6=$ nested PCR with $10 \mu \mathrm{l}$ standard PCR product form the negative control loaded in lane 3 and primers Y1.3 and Y1.4; lane $7=$ nested PCR with $10 \mu 1$ standard PCR product from the reaction loaded in lane 4 and primers $\mathrm{Y} 1.3$ and $\mathrm{Y} 1.4$.

more, testing of plasma and serum specimens from women carrying male fetuses showed that both of these specimen types contained Y-chromosome-specific DNA that could be detected by nested PCR (fig. 3). Similarly, positive results with genomic DNA from blood, plasma and serum, and negative results form the negative control samples were obtained in nested PCR by using the primer pair Y1.5/Y1.6 in the first step followed by reamplification in the nested step with the primer pair $\mathrm{Y} 1.7 / \mathrm{Y} 1.8$ (fig. 4).

After establishing the improved sensitivity of nested PCR, it was evaluated for the detection of Y-chromosome-specific DNA in the plasma of 55 pregnant women carrying male fetuses during pregnancy. The nested PCR assay detected Y-chromosome-specific DNA in 53 women. The sensitivity and the specificity of the plasmanested PCR were 96 and 88\%, respectively. To determine

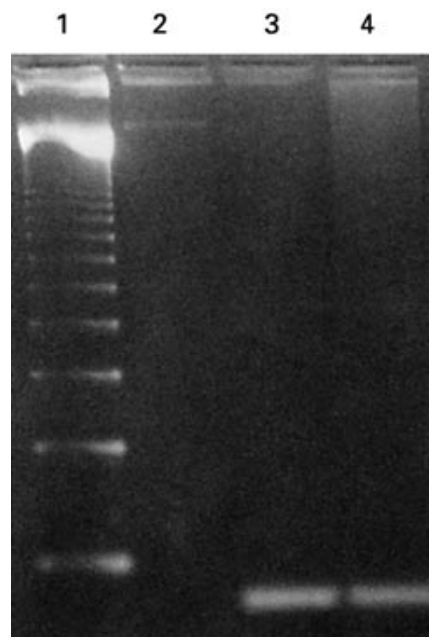

Fig. 3. Nested PCR by using DNA isolated from plasma and serum of a pregnant woman bearing a male fetus. Genomic DNA isolated from plasma and serum of a pregnant woman carrying a male fetus was subjected to standard PCR by using primers Y1.1 and Y1.2. The nested PCR was performed by reamplification of $10 \mu$ product from standard PCR with primers Y1.3 and Y1.4. Negative controls lacked the genomic DNA. The products were analyzed by gel electrophoresis as described in the 'Materials and Methods' section. Lane $1=$ Molecular weight marker (123-bp DNA ladder); lane 2 = nested PCR with negative control; lane $3=$ amplification of $95 \mathrm{bp}$ DNA in nested PCR with plasma, lane $4=$ amplification of 95 bp DNA in nested PCR with serum.

how long fetal DNA could be detected in the maternal circulation, plasma specimens from 22, 22 and 30 women delivering a male baby were tested for the presence of $\mathrm{Y}$ chromosome-specific DNA after 2 and $24 \mathrm{~h}$ and 7 days post partum, respectively. The results showed that all the women were positive for Y-chromosome-specific DNA at $2 \mathrm{~h}, 73 \%$ were positive at $24 \mathrm{~h}$ and none was positive at 7 days after delivery (table 2). Thus, within 1 week of delivery, the male-specific fetal DNA could not be detected in the plasma of women carrying male fetuses during pregnancy.

\section{Discussion}

In this study, we have demonstrated the presence of Y-chromosome-specific DNA sequences in the maternal specimens of women bearing male fetuses by using highly sensitive nested PCR. In previous reports, in which standard PCR was used, it was shown that Y-chromosome- 


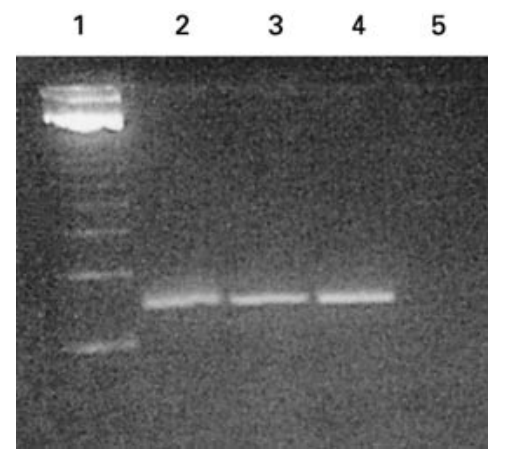

Fig. 4. Nested PCR with primers $\mathrm{Y} 1.5 / \mathrm{Y} 1.6$ and $\mathrm{Y} 1.7 / \mathrm{Y} 1.8$ and DNA isolated from peripheral blood, plasma and serum of a pregnant woman bearing a male fetus. Genomic DNA isolated from peripheral blood, plasma and serum of a pregnant woman carrying a male fetus was subjected to standard PCR by using primers Y1.5 and Y1.6. Negative controls lacked the genomic DNA. The nested PCR was performed by reamplification of $10 \mu$ product from standard PCR with primers $\mathrm{Y} 1.7$ and $\mathrm{Y} 1.8$. The products were analyzed by gel electrophoresis as described in the 'Materials and Methods' section. Lane 1 = Molecular weight marker (123-bp DNA ladder), lane $2=$ 198 bp DNA amplified in nested PCR with peripheral blood; lane $3=198$ bp DNA amplified in nested PCR with plasma; lane $4=$ 198 bp DNA amplified in nested PCR with serum; lane $5=$ nested PCR with negative control.

Table 2. Detection of Y-chromosome-specific DNA in plasma of women bearing male fetuses during pregnancy and after delivery

\begin{tabular}{lcccc}
\hline \multirow{2}{*}{ Time of test } & \multirow{2}{*}{ Cases } & \multicolumn{2}{c}{ Nested PCR results } \\
\cline { 3 - 5 } & & & positive & positive, \% \\
\hline During pregnancy & & 55 & 53 & 96 \\
After delivery & $2 \mathrm{~h}$ & 22 & 22 & 100 \\
& $24 \mathrm{~h}$ & 22 & 16 & 73 \\
& 7 days & 30 & 0 & 0 \\
\hline
\end{tabular}

specific DNA sequences were detected in $80-87 \%$ of maternal plasma samples during pregnancy $[10,21]$. Our results demonstrate improved sensitivity by showing the detection of Y-chromosome-specific DNA in $96 \%$ of plasma specimens form pregnant women bearing male fetuses. This could have been due to the improved sensitivity of nested PCR as compared to standard PCR. This is because in nested PCR the initial starting template for the second round of PCR is actually the PCR product, and therefore the target region is in high copy number compared to the genomic template used in the first round of PCR.

PCR for Detection of

Med Principles Pract 2001;10:171-176
Our previous study using plasma from 25 women bearing female fetuses showed false positive Y-chromosome signals in $3(12 \%)$ of the specimens [15]. The false positive results were due to sporadic contamination, supporting the hypothesis of an almost unavoidable sporadic contamination in some tubes during PCR preparation [22]. On the other hand, false negative results of $4 \%$ could be due to the presence of inhibitors or a low concentration of fetal DNA in some samples [12].

To detect Y-chromosome-specific DNA, we targeted single as well as multiple copy DNA sequences in Y chromosomes. It has been shown in other systems that multiple copy targets have usually greater sensitivity than single copy targets [23]. However, in our study, the sensitivity of single as well as multiple copy targets was similar in both standard as well as nested PCR. These results could be explained on the basis that the sensitivity of amplification of a target in PCR, in addition to target copy number, also depends on the primers and size of the amplified DNA etc. [23].

The nested PCR results using specimens from pregnant women suggest that whole blood, serum and plasma samples are useful in determination of fetal sex and could be applicable to noninvasive prenatal diagnosis of genetic Y-linked abnormalities, single gene disorders or determination of fetal sex etc. The clearance of fetal DNA from maternal plasma to a nondetectable level within 7 days after delivery (table 2) shows that fetal DNA in maternal circulation exists only for a short time, and therefore it seems that its use in prenatal diagnosis will not be affected by previous pregnancies.

\section{Conclusion}

Our results suggest that highly sensitive rested PCR was reliably used in fetal sex determination and prenatal diagnosis can be done without interference from previous pregnancy.

\section{Acknowledgments}

This study was supported by Kuwait University Research Administration grant MO 037. 


\section{References}

1 Bianchi DW, Flint AF, Pizzimenti MF, Knoll JH, Latt SA: Isolation of fetal DNA from nucleated erythrocytes in maternal blood. Proc Natl Acad Sci USA 1990;87:3279-3283.

2 Adinolfi M: On a noninvasive approach to prenatal diagnosis based on the detection of fetal nucleated cells in maternal blood samples. Prenat Diagn 1991;11:799-804.

3 Adinofi M: Breaking the blood barrier. Nat Genet 1992;1:316-318.

4 Simpson JL, Elias S: Isolating fetal cells from maternal blood: Advances in prenatal diagnosis through molecular technology. JAMA 1993; 270:2357-2361.

5 Geifman-Holtzman O, Blatman RN, Bianchi DW: Prenatal genetic diagnosis by isolation and analysis of fetal cells circulating in maternal blood. Semin Perinatol 1994;18:366-375.

6 Simpson JL, Elias S: Isolating fetal cells in maternal circulation for prenatal diagnosis. Prenat Diagn 1994;14:1229-1242.

7 Adinolfi M: Non or minimally invasive prenatal diagnostic tests on maternal blood samples or transcervical cells. Prenat Diagn 1995;15: 889-896.

8 Price JO, Elias S, Wachtel SS, Klinger K, Dockter M, Tharapel, A Shulman LP, Phillips OP, Meyers CM, Shook D, Simpson JL: Prenatal diagnosis with fetal cells isolated from maternal blood by multiparameter flow cytometry. Am J Obstet Gynecol 1991;165:17311737.

9 Zheng YL, Carter NP, Price CM, Colman SM, Milton PJ, Hackett GA, Greaves MF, Ferguson-Smith MA: Prenatal diagnosis from maternal blood: Simultaneous immunophenotyping and FISH of fetal nucleated erythrocytes isolated by negative magnetic cell sorting. J Med Genet 1993;30:1051-1056.
10 Mulcahy HE, Croke DT, Farthing MJ: Cancer and mutant DNA in blood plasma. Lancet 1996;348:628.

11 Nawroz H, Koch W, Anker P, Stroun M, Sidransky D: Microsatellite alterations in serum DNA of head and neck cancer patients. Nat Med 1996;2:1035-1037.

12 Lo YM, Corbetta N, Chamberlain PF, Rai V, Sargent IL, Redman CW, Wainscoat JS: Presence of fetal DNA in maternal plasma and serum. Lancet 1997;350:485-487.

13 Zhong XY, Holzgreve W, Hahn S: Detection of fetal rhesus D and sex using fetal DNA from maternal plasma by polymerase chain reaction. BJOG 2000;107:766-769.

14 Lo YM, Tein MS, Lau TK, Haines CJ, Leung TN, Poon PM, Wainscoat JS, Johnson PJ, Chang AM, Hjelm NM: Quantitative analysis of total DNA in maternal plasma and serum: Implications for noninvasive prenatal diagnosis. Am J Hum Genet 1998;62:768-775.

15 Al-Yatama MK, Mustafa AS, Ali S, Abraham S, Khan Z, Khaja N: Detection of Y-chromosome-specific DNA in the plasma and urine of pregnant women using nested polymerase chain reaction. Prenat Diagn 2001;21:399402.

16 Lo YM, Zhang J, Leung TN, Lau TK, Chang AM, Hjelm NM: Rapid clearance of fetal DNA from maternal plasma. Am J Hum Genet 1999; 64:218-224.
17 Mustafa AS, Ahmed A, Abal AT, Chugh TD: Establishment and evaluation of a multiplex polymerase chain reaction for detection of mycobacteria and specific identification of $\mathrm{Myco}$ bacterium tuberculosis complex. Tuber Lung Dis 1995;76:336-343.

18 Mustafa AS, Khan I, Fatania HR: Molecular Biology in medicine, current status and future prospects. Health Sciences Centre, Faculty of Medicine, Molecular Biology Workshop Proc, 1997, pp 32-36.

19 Lo YM, Patel P, Sampietro M, Gillmer MD, Fleming KA, Wainscoat JS: Detection of single-copy fetal DNA sequence from maternal blood. Lancet 1990;335:1463-1464.

20 Melkonyan HS, Lichtenstein AV, Umansky SR: DNA from dying cells passes through the kidney barrier in a polymeric from suitable for PCR analysis: A perspective diagnostic tool; in Proc Diagnostic Gene Detection and Quantitation Technologies, Int Business Commun, San Diego, June 1997.

21 Honda H, Miharu N, Ohashi Y, Ohama K Successful diagnosis of fetal gender using conventional PCR analysis of maternal serum. Clin Chem 2001;47:41-46.

22 Lagona F, Sid M, Papasergio N, Ferrai A, Ferrari $\mathrm{M}$, Cremonesi L: Multiple testing in fetal gender determination from maternal blood by polymerase chain reaction. Hum Genet 1998 ; 102:687-690.

23 Mustafa AS, Abal AT, Chugh TD: Detection of Mycobacterium tuberculosis complex and nontuberculous mycobacteria by multiplex polymerase chain reaction. East Mediterr Health J 1999;5:61-70. 